4. Макаров В.В. Основные принципы философии пола: Ст. первая. Биологический диморфизм, гендерная симметрия // Женщина в российском обществе. 2001. №2. С. 17.

5. Макаров Д. Примеряя трагическую маску Федры / Д. Макаров // [Электронный peсурс] - Режим доступа: http://www.ijp.ru/razd/pr.php?failp=12000601448 - Дата обращения: 04. 03. 2017.

6. Охотникова С.Р. Гендерные исследования в литературоведении: проблемы гендерной поэтики / С. Р. Охотникова // [Электронный ресурс] - Режим доступа: http://www.a-z.ru/women_cd1/html/gender_issledovanija_v_literature.htm. - - Дата обращения: 02.02.16

7. Пушкарь Г.А. Типология и поэтика женской прозы. Гендерный аспект [Электронный pecypc] - Режим доступа: http://www.twirpx.com/file/707089/- Дата обращения: 11.10.16.

8. Самсонова А.В. Гендерная проблематика английской прозы на примере романов Филдинг Хелен «Дневник Бриджет Джонс» и Дуги Бримсон «Кое-что о Билли» / А.В. Самсонова, С.Н. Барашкова // [Электронный ресурс] - Режим доступа: http:/nti.s-vfu.ru/downloads/doc/XVII\%20конференция\%20том\%202\%20Секции\%2047.pdf - Дата обращения: 27.02.2017.

9. Хеффе О., Малахова В.С. Современная западная философия. Энциклопедический словарь / Под. ред. О. Хеффе, В.С. Малахова, В.П. Филатова, при участии Т.А. Дмитриева. М., 2009, с. 12-14. - [Электронный ресурс] - Режим доступа: http://ponjatija.ru/node/11223 - Дата обращения: 02.02.2017

\title{
Концепт «мистика» в повести Н.В. Гоголя «Вий»
}

Седина Д.Р., студентка, Технический институт (филиал) Северо-Восточного федерального университета, 2. Нерюнгри E-mail: nieftisova@mail.ru

Научный руководитель: к.ф.н., доцент Яковлева Л.А.

Целью данной статьи является рассмотрение структуры концепта «мистика» на примере произведения Н.В. Гоголя «Вий».

Актуальность работы обусловлена тем, что изучение художественной картины мира писателя является неисчерпаемым средством познания и осмысления как картины мира, так и творческой позиции личности.

Прежде чем приступить к исследованию концепта мистика в творчестве Н.В. Гоголя, необходимо ознакомится с взятым за основу алгоритмом концептуального анализа художественного текста, предложенным Л.Г. Бабенко, Ю.В. Казариным:

1) Выделение предтекстовых пресуппозиций, важных для формирования концептуального пространства текста.

2) Анализ семантики заглавия и его семантического радиуса.

3) Проведение психолингвистического эксперимента с целью выявления набора ключевых слов текста. 
4) Анализ лексического состава текста с целью выявления экспрессивных и образных средств.

5) Выявление повторяющихся слов, сопряженных парадигматически и синтагматически с ключевыми словами.

6) Процедура семантического вывода абстрактного имени-репрезентанта текстового концепта, опирающаяся на обобщение результатов анализа, полученных на первых пяти его этапах.

7) Обобщение всех контекстов, в которых употребляются ключевые слова носители концептуального смысла, с целью выявления характерных свойств концепта: его атрибутов, предикатов, ассоциаций, в том числе образных.

8) Структурирование концептосферы: выделение ядра - базовый когнитивнопропозитивной структуры, приядерной зоны - основной лексико-фразеологической репрезентации, ближней и дальней периферии [1, стр. 344].

Таким образом, выбор данной методики поможет нам достаточно детально изучить концепт «мистика» в повести «Вий».

Перейдем к более конкретному разбору структуры концепта «мистика». Исходя из выбранной нами схемы, в первую очередь необходимо обратиться к словарям для анализа толкований ядра концепта, его базовой лексической репрезентации, т. е. лексемы «мистика».

Толковый словарь русского языка Ожегова, Шведовой дает следующие толкования: «МИСТИКА - и, ж. 1. Вера в божественное, в таинственный, сверхъестественный мир и в возможность непосредственного общения с ним. Средневековая м. 2. Нечто загадочное, необъяснимое (разг.). Все события последних дней - какая-то м. \| прил. мистический, -ая, -ое. Все события последних дней какая-то M.» [4, стр. 351].

Толковый словарь живого великорусского языка дает такое толкование слову мистика: «МИ́СТИКА ж. ученье о таинственном, загадочном, сверхъестественном, о сокрытом, иносказательном смысле и значении ученья и обрядов веры. Мисти́ческий, мисти́чный, сокровенный, скрытый, таинственный, темно иносказательный. Мистици́зм м. ученье, убеждение, понятия или наклонность к таинственному толкованию и обрядливости. Ми́стик м. предавшийся мистике, мистицизму. Мистифи́ровать кого, дурачить, тешиться обманом, вводить в длительное заблуждение, для одной забавы. Мистифика́ция ж. шуточный обман или содержание человека в забавной и длительной ошибке. Мисте́рия ж. таинственный обряд языческой веры; || зрелище, представление из Ветхого Завета, духовная драма» [3].

Современный толковый словарь изд. «Большая Советская Энциклопедия» толкует данную лексему следующим образом: «МИСТИКА (от греч. mystikos таинственный), религиозная практика, имеющая целью переживание в экстазе «непосредственного единения» с Богом, а также совокупность теологических и философских доктрин, оправдывающих и осмысляющих эту практику (см. Мистицизм)» [5].

Толковый словарь под редакцией Д.Н. Ушакова: «МИ́СТИКА, мистики, мн. нет, ·жен. (от ггреч. mystikos - таинственный).

1. Религиозная вера в непосредственное общение человека с ·m.н. потусторонним миром (·книж. ). Средневековая мистика. Мистика гностиков. Мистика хльстовства. 
2. перен. Нечто загадочное, непонятное, необъяснимое (·разг. ирон.). Это уж мистика какая-то! Мистику разводить» [7].

5). В Новом словаре русского языка дается следующее толкование лексемы «мистика»: «МИ́СТИКА - ж.

1) Религиозная вера в непосредственное общение человека с потусторонним миром.

2) перен. разг. Нечто непонятное, необъяснимое, загадочное» [6].

Общими положениями во всех толкованиях в первом значении являются семы «религиозная вера», а во втором значении «некая сверхъестественная сила, которая связывает человека с тайным миром». Но В.И. Даль выделяет лексему «мистика» в одном значении как учение о таинственном.

В качестве приядерной зоны концепта предстоит рассмотреть лексические единицы синонимического ряда и однокоренные слова, благодаря которым можно рассмотреть дифференциальные признаки. Из повести методом сплошной выборки извлекались лексические единицы с семами «сверхъестественное», «необъяснимое», «таинственное». Так, помимо слов мистика и мистический, были выбраны такие, как необъяснимый, необыкновенный, чудесный, мрачный, нечистая (сила), проклятая (ведьма), адская (ночь). Данные слова служат для создания мистической атмосферы, но различаются степенью качества.

Ближайшую периферию и дальнейшую периферию составляют образные репрезентации и эмоционально-оценочные смыслы, анализ которых помог вывести собирательный образ мистики, представленный в повести Н.В. Гоголя, и определить отношение автора.

В процессе филологического анализа текста важно выявить ключевые слова и рассмотреть наиболее частотные в нем лексические единицы, отражающие особую значимость для авторского сознания обозначаемых ими понятий, в аспекте их семантических трансформация, сочетаемости и позиционного распределения.

Следующим шагом анализа были определены ключевые слова анализируемого текста.

Лексема «мистика» имеет парадигму, которая состоит из 59 лексем.

Общее число лексем мы условно распределили по 6 категориям:

- о существе: скверная, черт, ведьма, священник, духи, мертвец, нечистые, (панночка) вся синяя, покойница, лики святых, потемневщие, выходцы (с того света), усопшая, труп, мертвые (уста), сатана, проклятая (ведьма), чудовища, Вий, (длинные) веки, железное (лицо).

- о пространстве: мрачность, стенание, мрак, мертвая (тишина), угрожающая (тишина), адская (ночь).

- о природе: вверх ногами (лошадь), в ночь (умерла), мутный (свет), черная (земля).

- о действиях: вой, (заснуть) мертвеики, умерла, убить, прокусила (горло), глядит (закрытылми глазами), выглянет (из гроба), открыла (мертвые глаза), летать (гроб), ияарапали (когтями), попадали (иконы), завязнувши (духи).

- абстрактные лексемы: заклятия, смерть, страшно (пронзительное), траурный, зло, чары, заклинания, несметная (сила), молитвы, грехи, панихида.

- об объектах: гроб, черный (гроб), церковь (ночью), (ведро) крови, капля крови (слеза).

В языковой картине мира Гоголя «мистика» предстает в самых различных 
образах. Сам концепт «мистика» часто является базовым, постоянно коррелирует с ключевыми для автора категориями «Пространство», «Время», «Человек».

Мы классифицировали данные ключевые категории.

Рассмотрим данную классификацию.

1. «Пространство». Повесть начинается с описания местного населения, писатель подчеркивает их непонимание религиозных текстов «то, что поют школяры, должно быть очень разумное».

Так же происшествия трех «чудесных ночей» происходит в «Храме Божьем»церкви. При описании церкви мы видим, что она стоит на какой-то такой видимой или невидимой грани. Это пограничное положение церкви подчеркивается: «вступили наконец за ветхую церковную ограду в небольшой дворик, за которым не было ни деревца, и открывалось одно пустое поле да поглощенные ночным мраком луга».

Мир фантастики и реальности переплетены друг с другом, в этом и заключается мистическое в бытии. Два мира приобрели предельную реальность. «Мертвячка» так же жива, как и главный герой.

Лексемы, характеризующие пространство - «освященная церковь», «гроб посередине алтаря», «волчий вой», «три дня после смерти», «обнаженное место», «мрак», «мертвая тишина», «жилище ведьмыл», «держалось в воздухе».

2. «Время». Время и пространство тесно связано друг с другом. Без первого не было бы и второго, и наоборот.

В данной повести Гоголь показывает как день, так и ночь. Но мистическое время суток для Николая Васильевича все же ночь «нельзя было ожидать ни звезд, ни месяца», «в ночь умерла панночка», «поглощенные ночным мраком», «ночь была адская».

В это время оживают все нечисти и мертвецы, всё светлое и прекрасное в мгновение становиться мрачным и устрашающим «страшно освященная церковь ночью», «темные образы святых».

3. «Человек». Главного героя повести зовут Хомой Брутом, и это обстоятельство тоже заслуживает внимания. Будучи учащимся семинарии и вроде бы христианином, Хома постоянно упоминает черта и вместо молитв постоянно читает заклинания, обращаясь к магии. Это происходит и во время ночного полета «Хорошо же!» - подумал про себя философ Хома и начал почти вслух произносить заклятия». И в церкви при начертании круга «очертил около себя круг, произнес несколько заклинаний».

На протяжении всей повести главного героя преследуют странные образы:

$\begin{array}{ll}\text { - } & \text { Панночка } \\ \text { - } & \text { Вий } \\ \text { - } & \text { Нлье Духи } \\ \text { - } & \text { Ведтми } \\ \text { - } & \text { Черт }\end{array}$

Таким образом, концепт «мистика» в произведении Н.В. Гоголя представлен широко и разнообразно, что свидетельствует о важности, актуальности и ценности этого концепта в построении мира произведения автора. Концепт «мистика» - в творчестве писателя занимает особое место, которое прослеживается во всем: в пространстве, времени и образах.

Семантическое наполнение лексем репрезентантов концепта «мистика» в 
повести Гоголя является, с одной стороны, отражения существующей мистической реальности, а с другой - желанием писателя подчеркнуть значимость и важность «мистической идеи» для самого себя и своих героев.

Список литературы:

1. Бабенко Л.Г. Лингвистический анализ художественного текста. Теория и практика: Практикум / Л.Г. Бабенко, Ю.В. Казарин. - 4-е изд., испр. - М.: Флинта: Наука, 2006. - 469 с.

2. Гоголь Н.В. Вечера на хуторе близ Диканьки. Миргород. -М.: Художественная литература, 1982. - 462с.

3. Даль В. Толковый словарь живого великорусского языка [Электронный pecypc]. - (Электрон.дан.). - Режим доступа: http://www. slovari.yandex.ru/ dict/dal/article/dal // - Загл. с экрана - Яз.рус.

4. Ожегов С.Ю., Шведова Н.В. Толковый словарь русского языка. - М.: Просвещение, 1992

5. Современный толковый словарь. / под ред. А.М. Прохорова [Электронный pecypc]. - Режим доступа: http://www.twirpx.com/file/1389507/

6. Современный толковый словарь русского языка Т.Ф. Ефремовой [Электронный pecypc]. - (Электрон.дан.). - Режим доступа: http://www. dic.academic.ru/contents.nsf/efremova //

7. Толковый словарь русского языка Д.Н. Ушакова [Электронный ресурс]. (Электрон.дан.). - Режим доступа: http://www.slovari.yandex.ru/ dict/ushakov //

\section{Идейно-эстетическое своебразие романа Амма Аччыгыйа «Сааскы кэм»}

\section{Сидорова С.P., студентка, Северо-Восточный федеральный университет, 2. Якутск E-mail: sandaarywka97@gmail.com}

\section{Научный руководитель: к.филол.н., доцент Герасимова Е.С.}

В якутском литературоведении творчество Н.Е. Мординова нередко воспринимали в идеологизированном ракурсе, а его метод трактовали как образец социалистического реализма. Но искусство писателя не укладывается в прокрустово ложе официального метода советской литературы. Амма Аччыгыйа не просто изобразил жизнь «в ее революционном развитии», а явился, согласно справедливому замечанию В.М. Переверзина, «выразителем духовных и социальных исканий народа саха в эпоху революционных изменений общества» [3, с.83]. «Народноцентричный» характер его эстетики в полной мере был реализован в романе «Весенняя пора», по праву ставшем «главной книгой литературы саха», своего рода «Книгой нации» [3, с. 84].

«Весенняя пора» - это произведение эпопейного плана с универсальным охватом жизненных явлений, с обстоятельным изображением человеческих характеров в их многообразных связях с общественным бытием. Автор романа глубоко раскрыл 